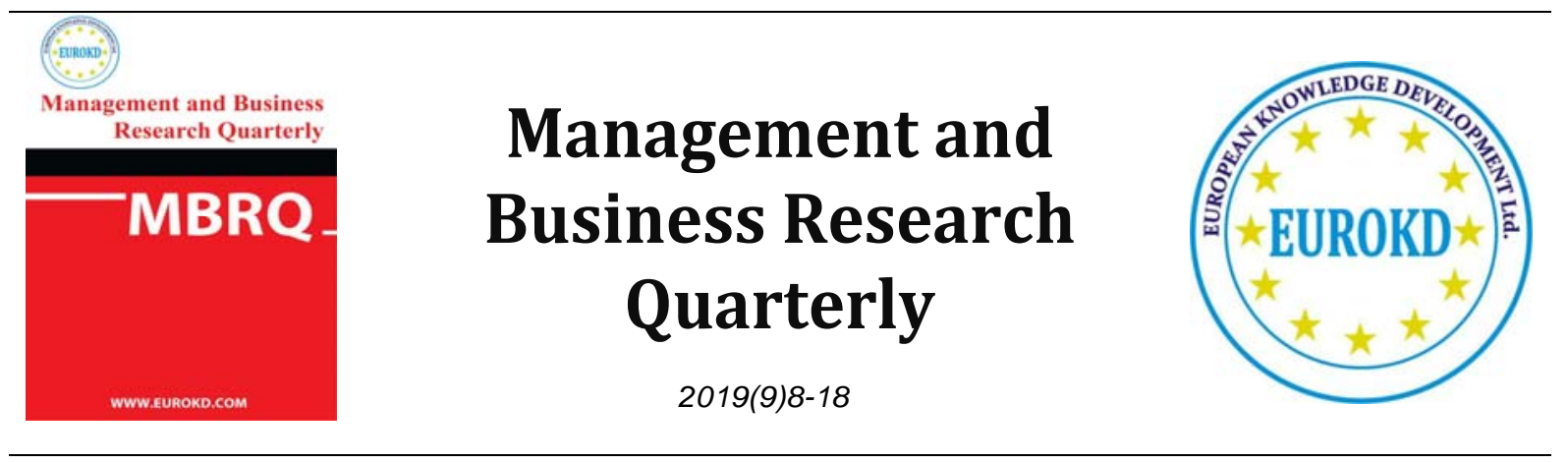

\title{
Increasing Three Times the Selling Price of Horticultural Products Using Social Media
}

\author{
Moh. Erfan Arif*, Pungky Syah Banar \\ Management Department, Faculty of Economics and Business, Universitas Brawijaya, Indonesia \\ Received 19 April 2019 Accepted 11 May 2019

\begin{abstract}
This study aims to determine the benefits of social media as a tool to market horticulture products in Bulukerto Village, at Batu City, East Java-Indonesia. The intended benefit of this study is to find out whether there is an increase in sales price result or profit that received by the farmers using social media, such as Facebook, Instagram, and WhatsApp. This study is conducted by applying a qualitative approach. Data are obtained through in-depth interviews from the relevant informants with judgmental sampling. One of the criteria of the selected informants is that they only make changes in marketing their products with social media to increase their products prices. The results of this study indicate that there are significantly large selling price, as received by farmers. Greater channels, so that farmers can meet with end consumers directly. Before marketing the product by using social media, the product price obtained amounted to only IDR. 5,000/kg, while after using social media the price increased to approximately IDR. 10,000 to IDR $15,000 / \mathrm{kg}$.
\end{abstract} \\ profits are obtained by farmers driven by the role of utilizing social media to cut long distribution
}

Keywords: Benefit, Increase, Price, Social Media, Distribution Chain

\section{Introduction}

The agricultural sector becomes one of the main priorities in each of Indonesia's development plans because this sector is inseparably related to the basic needs of the community. The carrying capacity of the agricultural sector provides a major influence on economic growth since Indonesia is an agrarian-style country. Not only does act as an economic driver of the rural area, the agricultural sector is also able to provide basic needs in the form of rice for national needs. 
Central Bureau of Statistics (BPS) data in 2017 points out that the profession as a farmer becomes the first choice from 39.6 million Indonesians. Of the total farmers, the majority lives in conditions away from prospererity. BPS (2014) revealed that one of the causes for many farmers living in such conditions is the low selling price of agricultural products. The low selling price is among other reasons caused by vulnerable agricultural products, forcing the farmers to immediately sell to middlemen and to the length of the marketing chain from farmers to end consumers.

The marketing channel is a series of interdependent organizations involved in the process of making products or services to consumers (Kotler and Keller, 2016). Daniel (2002) emphasizes shorter marketing chain of an agricultural product will result in lower costs and lower trading margin. As a result, the lower the price the consumer must pay and the higher the price that the producer receives, the marketing channel will be more efficient.

In general, the marketing channels for horticulture products have the following pattern (Istanto, et.al, 2016) such as:

a. Farmers - Village traders - Collectors - Wholesalers - Retailers - Consumers.

b. Farmers - Collectors - Wholesalers - Retailers - Consumers.

c. Farmers - Village traders - Wholesalers - Retailers - Consumers.

d. Farmers - Wholesalers - Collectors - Retailers - Consumers.

e. Farmers - Collector traders - Consumers.

f. Farmers - Village traders - Collectors - Retailers - Consumers.

g. Farmers - Collector traders - Consumers.

Problems regarding the length of the marketing chain were also experienced by farmers in Bukukerto Village, at Bumiaji District of Batu City. Farmers in Bulukerto Village highly depend on middlemen having a long marketing chain (Choiriyah, 2017). As a consequence, the length of the marketing chain will affect the selling price of agricultural products and the benefits received by farmers.

Soekartawi (2010) argues that agricultural product selling in developing countries becomes weak aspects of marketing or known as weak market competition. Agricultural products generally have seasonal characteristics, which are always fresh (freshable), easily damaged, numeruos with little value (bulky), local and specific (can not be produced in all places). This feature certainly will affect the mechanism of agricultural product marketing. Therefore, product prices tend to fluctuate and farmers are often disadvantaged.

Transportation facilities play a very important role in supporting the horticulture products to reach consumers. Considering that horticulture products must be consumed in a fresh form and are easily damaged if not seriously and quickly handled causing more harm than good to farmers (Zulkarnain, 2010).

The agricultural development of the horticulture sub-sector which includes commodities of vegetables, fruit, ornamental plants and biopharmaca becomes one of the important foreign exchange earnings. Therefore, horticulture farming still has a promising economic potential. The problem of developing horticultural agribusiness generally lies in the aspects outside the farm (off farm) rather than farming aspects (on farm) because the constraints on developing horticultural agribusiness are more commonly found in post-harvest handling and marketing (Irawan, 2003). 
The problem concerning with the long marketing channel of agricultural products would affect the marketing chain to be shorter. By shortening the marketing channel, farmers will gain more benefits. One purposed way which can be executed is by involving the advancement of information technology (Choiriyah, 2017). The assistance of information technology will be able to shorten the distance between farmers and end consumers.

The use of this technology has been applied by farmers in China. Farmers realize that there is the potential for using e-commerce through social media in more widely marketing their agricultural products to reach more market coverage. By this effort, the product marketing chain will be shorter as farmers will directly meet the end consumer; therefore, the farmers can get higher prices compared to having to sell to middlemen (Shu, 2007).

The internet creates a new channel for interactive communication among consumers, producers and other business partners. Oviliani (2000) mentions that information technology engaging the internet allows farmers to continuously interact and work together in product development, marketing, shipping, service, and technical support. In addition, the recent use of online marketing or e-commerce through social media is favored by both large and small producers as well as general retailers, due to easier means of promotion to reach consumers in terms of introducing or selling their products.

This advancement in information technology is utilized by horticultural farmers in Bulukerto Village, at Batu City. Farmers who are still young realize the benefits of information technology to market their agricultural products. The commonly used application is social media which is easy to operate and to help market its products. Fortunately, farmers who are aged are still easily more adaptive in utilizing existing information technology.

Based on the related problems, this study focuses to determine the benefits of social media as a tool to market horticulture products in Bulukerto Village, at Batu City, East Java-Indonesia. The intended benefit of this study is to find out whether there is an increase in sales price result or profit that received by the farmers using social media, such as Facebook, Instagram, and WhatsApp.

\section{Literature Review}

Most producers do not directly sell their goods to end users between them; as there is a group of intermediaries who carry out various functions. These intermediaries are form marketing channels (also called trade channels or distribution channels). Marketing channels involve marketing activities to facilitate the delivery of goods and services from producers to consumers, to meet their daily needs (Tjiptono, 2008).

According to Djaslim (2004), marketing channels can be viewed as sets of interpendent organizations involved in the process of making a product or service available for usage or consumption. Such definition includes three elements, which are: firstly, the existence of a group of marketing institutions. Secondly, there are activities or functions carried out by the institution. Thirdly, there is a direction of product movement and ownership from producers to consumers.

The marketing channel describes all activities contributing to food production. Channels that emphasize the needs of companies involved in marketing institutions are mainly in the production 
of food and fiber. Thus, it gives rise to use value or added value (form utility, time utility, place utility, and possession utility (Bailey and Jayson 2008).

Kotler and Keller (2016) state that marketing channels are an interdependent group of organizations which are involved in the process of making products and services for usage or consumption. The marketing channel contains an agreement which follows products or services after production and ends in the purchase and use by the end user.

The marketing channel has main function to move goods from producer to consumer. Marketing channels address the time, place and ownership gaps that separate goods and services from those who need or want them. The functions of the marketing channel members are as follows (Kotler and Keller, 2016):

a. Gathering information about potential customers and current customers, competitors, and other actors and strengths in the marketing environment.

b. Developing and disseminating persuasive communication to encourage purchases

c. Achieving price agreements and other requirements to affect transfer of ownership

d. Making order to producers

e. Obtaining funds to finance inventory at various levels in the marketing channel

f. Assuming risks associated with carrying out channel work

g. Providing smooth storage and movement of physical products

h. Providing bills for buyer payments through banks and other financial institutions

i. Supervising the transfer of ownership from the company

Nickels (2008) shows the factors that influence the selection of distribution channels which are as follows:

1. Market considerations, including consumer or industrial markets, number of potential buyers, geographic market concentration, number of orders, and buying habits.

2. Goods consideration, including unit value, size and weight of goods, damage to goods, technical properties, standard goods and orders, and the extent of product line.

3. Company considerations, including sources of expenditure, management experience and capabilities, channel supervisors, and services provided by the seller.

4. Intermediary considerations, including services provided by intermediaries, the use of intermediaries, the attitude of intermediaries to the policies of producers, the volume of sellers, and costs.

Channels usually describe the ongoing product movement from source to user, but there are also reverse flow channels, which are important in the following cases for: (1) reusing products or packaging; (2) repairing products for resale; (3) recycling products; and (4) disposing products and packaging (waste products). Some intermediaries play a role in reverse flow channels, including producer exchange centers, community groups, and traditional intermediaries such as soft drink brokers, garbage collection specialists, recycling centers, waste recycling brokers, and central processing warehouses. 


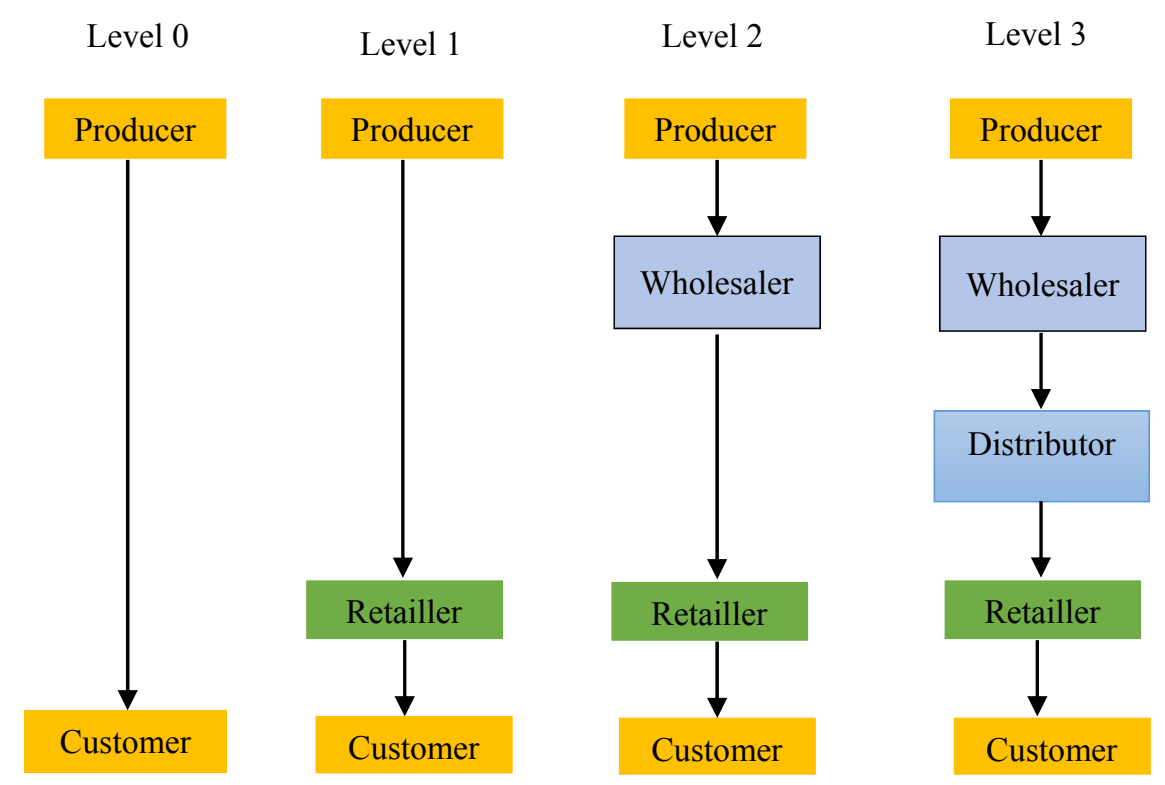

Figure 1. Level of Marketing Channels (Stanton, 2012)

Electronic commerce (e-commerce) provides a new concept which can be described as the process of buying and selling goods or services by engaging the World Wide Web Internet or conducted through information networks. According to Laudon and Laudon (2010), e-commerce involves a process of electronically buying and selling products by consumers and from companies to companies with computers as intermediaries for business transactions. According to Turban (2015), e-commerce means an electronic commerce that includes the process of buying, selling, transferring, or exchanging products, services, or information through computer networks, including the internet.

An important component in digital marketing today is social media. According to Kotler and Keller (2016), social media is a place for consumers to share information in the form of messages, images, sounds, and videos to others and with companies. While according to Kaplan and Haenlein (2010), social media is a group of internet-based applications built on the ideological and technological framework of the Web 2.0 platform to connect between individuals and individuals to share and gather online. Social media is now directly utilized by e-commerce companies for business development currently still dominated by Facebook.

The main outcome of the development and exploitation of Information and Communication Technology (ICT) and the Internet is the creation of a new type of website that helps people create, share, communicate and modify user-generated content, such as social media. Currently, there are hundreds of social media platforms worldwide. There are various types of platforms for users to follow and use such as: social networking, blogs, and discussion groups (Xiang dan Gretzel, 2010; Hanna, et. al. 2011; Pitt and Berthon, 2011).

The popularity of social media leads to a new communication framework, in which individuals have the power to interact, collaborate, and share information. Through this process, individuals create 
new trends which mostly affect the ways companies interact with customers (Mangold dan Faulds, 2009, Freberg, et. al. 2011).

Garret (2014) defines social media marketing as a tool, service, and communication that facilitates relationships between people with one another having the same interests or interests. Social media marketing according to Salvatore (2005) is a marketing medium which is conducted online with the involvement of the community in it to form a market in cyberspace. Social media becomes a platform that is easily accessible to anyone with the internet, opening up opportunities for companies to increase their brand awareness and to facilitate conversations with customers.

Another benefit of social media in marketing a product in trading activities is to reduce costs having a big impact on a business (Daniel, 2015). Problems regarding the extension of the marketing chain that are faced by producers can be overcome by using this approach, including the problems faced by farmers in selling their products that must pass through several distribution chains.

Neti (2011) describes the role of social media for marketing activities of a product, such as:

1. To provide identity about the product offered

2. To act as marketing research in an effort to find information about consumer needs

3. To be utilized as a communication link between marketers and consumers to maintain relationships with consumers.

4. To bring companies closer to consumers. Consumers can reduce the time that may be used only to see products directly; and to display products at all times.

5. To build customer engagement.

Social Media Marketing is also known as SMO (Social Media Optimizer) by providing additional channels to support and get customers. There are two categories of SMOs, such as:

1. Social media features added to the content itself such as social content, sharing buttons, user ratings and polling tools.

2. Promotion activities from social media apart from the content being promoted, including blogging, commenting on blogs, discussions and status updates on social networks.

According to previous study conducted by We Are Social and Hootsuite (2018), the average Indonesian population spends about three hours 23 minutes a day accessing social media. From the report entitled "Essential Insights into the Internet, Social Media, Mobile and E-Commerce Use around the World" which was published in January 2018, Indonesia's total population was 265.4 million; in which active social media users reached 130 million with 49 percent penetration. Of the 130 million social media users, $43 \%$ uses Youtube, $41 \%$ uses Facebook, 40\% uses WhatsApp and $38 \%$ uses Instagram.

\section{Methodology}

This study is categorized as a descriptive study with a qualitative approach for exploring and understanding meaning from a number of individuals or groups of people which are ascribed to social or humanitarian problems (Creswell, 2016); as well as to explore information in depth, to all responses, not with yes or no answer (Perreault dan McCarthy, 2006).

A case study method is applied in this study which intensively concentrates on a particular object as a case. Case study data are obtained from all concerned parties. In other words, this study collects 
various sources but is limited in the cases studied (Nawawi, 2003). This research using judgment sampling. A sampling technique in which subjects are selected based on their expertise related to research topics. This technique can be used as an appropriate way to obtain detailed information needed. The questions used cannot be generalized to the entire population. Judgment Sampling involves selected people who best understand the information we need specifically (Sekaran and Bougie, 2014).

This study aims to deeply explain phenomena through primary data collection from interviews. This research was conducted in Bulukerto Village, at Bumiaji District of Batu City, Indonesia. Bulukerto is a village with an agricultural pattern enriched with people from diverse religious backgrounds and socio-economic conditions. This location was chosen for several reasons, including: farmers have started to use social media and there are farmers from youth groups who can use information technology to sell their agricultural products.

\section{Result and Discussion}

Informants in this study amount to 5 people who work as farmers. Each has the following identity:

Table 1.1. Identity of Informants

\begin{tabular}{lccccc}
\hline No & Name & Age & Education & $\begin{array}{c}\text { Enterpreneural } \\
\text { Duration }\end{array}$ & Utilized Media \\
\hline 1 & HS & 27 Years & Undergraduate & 5 Years & Instagram, Facebook, dan Whatsapp \\
\hline 2 & SG & 36 Years & High School & 22 Years & Facebook, dan Whatsapp \\
\hline 3 & AH & 33 Years & High School & 13 Years & Facebook, dan Whatsapp \\
\hline 4 & AW & 27 Years & High School & 8 Years & Facebook, dan Whatsapp \\
\hline 5 & SL & 43 Years & High School & 28 Years & Facebook, dan Whatsapp \\
\hline
\end{tabular}

Source: Primary Data Processed by Researcher (2018)

The majority of farmers are still in productive age, being still relatively young and is expected to be more productive in managing land and responding to the advancement of information technology to support its business. This is similar to study conducted by Soekartawi (2005) stating that the younger the age of farmers, they will have the enthusiasm to know what is not known; thus, they rapidly could adopt and respond to innovation.

From the results of interviews, it was revealed that farmers in Bulukerto Village experienced benefits obtained due to the existence of social media. The social media platforms used by farmers to sell their products are Facebook, WhatsApp and Instagram. Some of the benefits expressed by farmers in Bulukerto Village include: this social media can be used for new, wide range, and 24 hour- market; and the sale price is more expensive when selling through social media.

With so many benefits, farmers are more interested in selling their agricultural products through social media, allowing the farmers to have the power to determine prices and act as a price maker to gain a much higher price compared to selling through middlemen as price takers. These beneficial outcomes encourage farmers to change the way they sell their agricultural products, which initially and conventionally involved through middlemen. The results of this study strengthen the previous research conducted by Prastuti (2013) which states that the obtained advantageous factors have a 
significant and positive influence on the adoption of social media. Based on the obtained data and previous research, the researcher concludes that the higher the benefits obtained from social media, the adoption of social media will be increasingly massive.

Other benefits of using social media are found out in terms of time efficiency, lasting for 24 hours a day. In addition, selling products through social media has a wider range and even without limits. Farmers no longer need to come all the way to the market to sell their products. By using social media, farmers do only stay at home and post it through their social media. Not only does they concern with time efficiency, but farmers can also be more efficient in terms of their energy. The significant difference felt by horticultural farmers upon involving social media rather than selling their products through middlemen, previously determining higher prices due to retail means of selling. It is impossible to purchase at wholesale, once the middlemen are engaged. Normally, when the middlemen buy wholesale, the set price will be cheaper and the profits obtained by farmers will be lower. Even though it is sold in retail-level, farmers feel happier because it is easier to find buyers.

Based on the provided benefits by the use of social media, various business opportunities exist. Farmers are able to create new business opportunities after using social media in selling their products. The opportunity emerges not only in the process of buying and selling horticultural agricultural products, but it also creates a new business, such as in picking their agricultural products. Farmers simply post photos of their agricultural products that have not been harvested on social media; thus, requests for picking tours might immediately arrive.

Product marketing using social media for farmers in Bulukerto Village might significantly raise the farmers' income, not only from selling agricultural products, but also from additional income from picking tours. Surely, the demand for picking tours comes from the end consumers, willing to pay higher prices.

The utilization of social media for farmers also additionaly provides useful knowledge towards demanded agricultural products by consumers. The case, unfortunately sticks to the fact that agricultural products are planted in accordance with existing habits without making product innovations. In fact, agricultural products as demanded by consumers are quite diverse, such as:

\begin{tabular}{lll}
\hline No & Detail & Type of Plant/Crop \\
\hline 1. & Income crop & 1. Flower \\
\hline \multirow{2}{*}{ 2. } & \multirow{2}{*}{ Main/staple crop } & 1. Apple \\
& & 2. Vegetable \\
\hline \multirow{2}{*}{ 3. Side crop } & 1. Sweet potato/ cassava \\
& & 2. Sweet corn \\
\end{tabular}

Currently, the selection of products grown by farmers has been only based on speculation, causing a negative impact when the harvest season arrives; as farmers often suffer losses because the product does not sell well. The researcher found out an actual instance when farmers speculate that planting apples was no longer chosen when the harvest of orange fruit is demanded more by consumers. 
Through the existence of social media, farmers shall experience a relief about choosing the products to be planted. Social media accommodates farmers to foresee the most demanded products, assisting the farmers to properly plant their products (agricultural related plants).

Besides selling through social media, farmers also utilize social media as a promotional medium by posting their agricultural products in the Facebook group completed with price specifications and locations. Promotion through social media is thought as the most effective step thanks to its numerous users. As a result, a promotional activity carried out by farmers on social media can reach a large number of consumers or potential consumers (Kurniawan, 2017).

Facebook as one of preferred social media platforms has the most populated users in Indonesia. On this basis, promotion using Facebook becomes the right choice due to providing more opportunities. In addition, Facebook gives a very easy way to find groups or pages for its users. Kurniawan (2017) emphasizes that groups or pages on Facebook enable social media users to gather and find what they like most.

Farmers in Bulukerto Village often suffer losses when selling through middlemen. Farmers only act as a price taker and can only accept middlemen's decisions. However, with the utilization of social media, farmers now have the choice to sell to other consumers in an easier way. Social media provides a more profitable way of selling than does through middlemen as social media the marketing chain becomes shorter; therefore, the obtained profits are higher.

In certain circumstances, the middlemen can play a price which results in the loss of the farmer. Unfortunately, middlemen sometimes provide incorrect information, particularly when the market price of certain product experiences a decline contrasting with the real fact. Commonly, agricultural produts from farmers is bought by middlemen at low prices. Farmers easily believe what the middlemen say since farmers do not have a reference to sell their products other than from middlemen.

The problem with the information asymmetry provided by the middlemen can be reduced by utilizing social media. Upon social media engagement, farmers in Bulukerto Village can use a 0 (zero) level channel, in which sales are directly made to end consumers and not through other intermediaries. Farmers reveal that the turnover of earned profits when selling through social media can reach three times higher compared to conventional selling method.

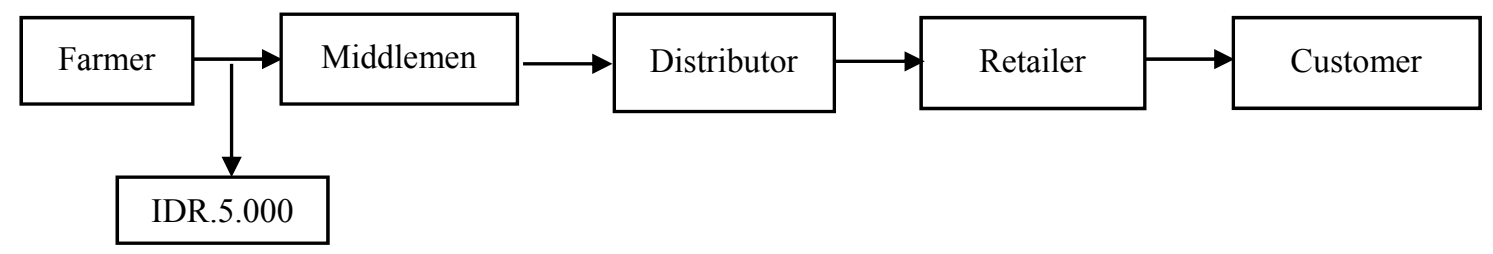

Figure 2.Level 3 Marketing Channels before Using Social Media

The process of delivering these agricultural products must conventionally passes through various levels. Figure 2 shows that the product of the farmer must pass the four stages or levels to reach the final consumer. It is obvious that each level will take advantage of its business sustainability. If the 
product delivery process has a long chain, the purchase price of agricultural products from farmers will be very low, affecting the low profits for farmers.

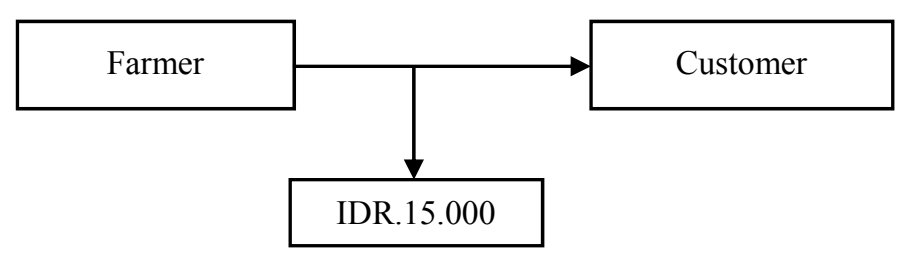

Figure 3. Level 0 Marketing Channels after Using Social Media

In such long marketing channel connecting between farmers and end consumers, the closer distance between farmers and consumers will have consequences for the high prices received by farmers. The difference in benefits gained between those who do not use social media and those who use it, is 3 times higher. The original farmers mostly gain product price around IDR. 5,000/kg, while using social media providing the price around IDR $15,000 / \mathrm{kg}$. This situation definitely provides advantage for farmers because it can increase their income which has been one of the main problems in the agricultural sector.

\section{Conclusion}

From the presented result and discussion, the researcher concludes that horticultural farmers in Bulukerto Village, at Batu City who utilize social media can gain more effective outcome in selling their agricultural products. Social media beneficially used by farmers, cuts the existing marketing chain. Farmers in Bulukerto village, who initially experience problems related to long distribution chains, are now assisted by using social media Facebook, Instagram and WhatsAap. In addition, farmers in Bulukerto village also get more profits. If farmers sell their products through middlemen, the price of the product is only IDR. 5,000/kg, contrasted with selling their products through social media. Upon using social media, farmers in Bulukerto village get a product price of IDR. 15,000/kg. This certainly gives significant comparison to increasing income for farmers, previously becoming a main problem for farmers in Batu City or in Indonesia.

\section{References}

Bailey, N. and Jason, Lusk. 2007. Agricultural Marketing and Price Analysis. Prentice Hall.

Choiriyah, Lailis Nurul. 2017. Marketing Efficiency Analysis of Batu 55 Tangerines (Case Study in Bulukerto Village, Bumiaji District, Batu City). Agribusiness Study Program, Faculty of Agriculture, Brawijaya University).

Creswell, John. 2016. Research Design: Qualitative, Quantitative and Mixed Method Approaches. Yogyakarta: Pustaka Belajar.

Daniel, Iman K., Zainul Arifin dan Mawardi, Kholid M. 2015. The Effect of Social Media Marketing on Consumer Awareness on International Products. Business Administration Journal Vol. 24 No. 1

Djaslim, Saladin, 2004. Marketing Management (Analysis, Planning, Implementation and Control). Bandung: CV. Linda Karya.

Freberg, K., Graham, K., McGaughey, K. and Freberg, L., A. (2011). Who are the Social Media Influencers? A Study of Public Perceptions of Personality. Public Relations Rewiev, 37, p 90-92

Garrett, Chris, 2009. Are You Ready for Social Media (Online). (Chrisg.com/social- media-2009, (acessed in 10 October 2018). 
Hanna, R. Rohm, A., and Crittenden, V.L., 2011. We're All Connected: The Power of Social Media Ecosystem. Business Horizons, 54, p 265-273.

Istanto, Roessali, Wiludjeng dan Setiadi, Agus, 2016. Marketing Analysis of Cabbage (Brassica Oleracea L. Var. Cagitata L) in Agribusiness Sub Terminal (Sta) Jetis Semarang Regency. MEDIAGRO. Agricultural Product Journal, Vol. 12. No.2.

Irawan, B. 2003. Building Integrated Horticulture Agribusiness with Market Area Bases. Agro Economic Research Forum. 21. (1). Center for Research and Development of Agricultural Social Economics. Bogor.

Kaplan, Andreas \& Haenlein, Michael, 2010. Users of The World Unite! The Challenges and Opportunity of Social Media. Business Horizon

Kotler, Philip dan Kevin Lane Keller. 2016. Marketing Management, $15^{\text {th }}$ Edition. New Jersey: Pearson Prentice Hall, Inc.

Kurniawan, Puguh. 2017. Application of Instagram Social Media as Modern Marketing Communication at Burneh Batik. Kompetensi Vol. 11 No. 2

Laudon, Kenneth C., dan Jane, P. Laudon. 2010. Management Information System: Managing the Digital Firm. New Jersey: Prentice Hall.

Mangold, G. and Faulds, D. (2009). Social media: The New Hybrid Element of the Promotion Mix. Business Horizons, 52, p 357365

Nanawi, Hadari. 2003. Social Research Method. Yogyakarta: Gajah Mada University Press.

Neti, Sisira, 2011. Social Media and Its Role in Marketing. International Journal of Enterprise Computing and Business System Vol. 1 No. 2

Nickels, William G. 2008. Modern Marketing Management. Yogyakarta: Liberty Offset

Oviliani, Yenty, Yuliana, 2000. Use of Internet Technology in Business. Journal of Accounting and Finance Vol. 2 No. 1

Perreault, Cannon, W.D., dan McCarthy, E., J., 2006. Global Managerial Approach. Jakarta: Salemba Empat.

Pitt, L. and Berthon, P. (2011). Just When You Thought it was Safe to Go Back into the Web: Marketing Meets Web 2.0, Social Media, and Creative Customers. Business Horizons, 54, p 181-183.

Prastuti, Sulistyorini, Royanti, Ika Nur dan Yunianto, Era. 2012. Effect of Adoption of E-Commerce on Business Success. Pekalogan City R \& D Journal.

Salvatore, Dominick, 2005. Managerial Economy in the Global Economy. Jakarta: Salemba Empat.

Shu, Geng, Tian-zhi, Ren dan Mao-hua, Wang, 2007. Technology and Infrastucture Consideration for E-Commerce in Chinese Agriculture. Agricultural Sciences in Chinese 6(1): 1-10.

Sekaran, Uma, Bougie, Roger, 2014, Research Methods for Business, John Wiley \& Sons Ltd, United Kingdom.

Soekartawi, 2010. Guide to Making Proposals for Agricultural and Rural Projects. Yogjakarta: ANDI.

Stanton, William, J. 2012. Marketing Principle. Jakarta: Erlangga.

Tjiptono, Fandy, 2008. Marketing Strategy. Yogjakarta: Andi.

Turban, Efrain, et.al, 2015. Electronic Commerce: A Managerial and Social Networks Perspective, $8^{\text {th }}$ Edition. Switzerland: Springer International.

Xiang, Z. and Gretzel, U. (2010). Role of Social Media in Online Travel Information Search. Tourism Management, 31, p 179-188.

Zulkarnain, 2010. Introduction to Horticulture. Bumi Aksara. Jakarta.

http://hootsuite.com Pengguna Sosial Media di Indonesia. (Acessed: Thursday 08/11/2018

http://www.wearesocial.com Pengguna Sosial Media di Indonesia. (Acessed: Thursday 08/11/2018

http://www.batukota.bps.go.id/ (acessed: Saturday 06/10/2018). 